18 ЦГАСО. Ф.Р. 751. Оп. 6. Д. 774, л. 120-121.

19 ЦГАСО. Ф.Р. 1186. Оп. 3. Д. 159, л. 51-53.

20 ЦГАСО. Ф.Р. 1186. Оп. 3. Д. 159, л. 56.

${ }^{21}$ См. Кульшанова А.А. Дефиниции "национальные меньшинства", "народ", "национальные отношения" - современные подходы // Наука, новые технологии и инновации. 2015. № 3. С. 166-168.

22 ЦГАСО. Ф.Р. 1230. Оп. 1. Д. 1. Л. 12-15.

\title{
THE NATIONAL EDUCATIONAL POLICY OF THE STATE IN HIGHER EDUCATION IN THE 1920-1930S (BASED ON THE MATERIALS OF THE MIDDLE VOLGA REGION)
}

\author{
(c) 2020 Sumburova Elena Ivanovna \\ $\mathrm{PhD}$ in History, Associate Professor \\ Samara State University of Economics \\ E-mail: elena-sumburova@yandex.ru
}

Keywords: national policy, USSR, middle Volga region, national minorities, higher school.

The article is devoted to studying the aspects of the educational policy of the Soviet government in the 1920-1930s among the numerous non-Russian peoples who lived in the USSR. On the basis of census data and archival documents of higher education institutions in the Middle Volga region, the author analyzes the main directions of government action and methods for improving the educational level among the indigenous population of the region.

УДК 93/94

Код РИНЦ 03.00.00

\section{ОПРЕДЕЛЕНИЕ ТРАДИЦИОННОЙ ИСЛАМСКОЙ РЕЛИГИОЗНОСТИ В РЕСПУБЛИКЕ ТАТАРСТАН}

\author{
(c) 2020 Яруллин Руслан Фаридович \\ студент \\ (c) 2020 Семакина Анастасия Александровна \\ студент \\ Казанский федеральный университет \\ E-mail: kit.kit@list.ru
}

Ключевые слова: ислам, Республика Татарстан, ханафитский мазхаб, традиционная религия, джадидизм, история ислама

Статья посвящена выявлению традиционной исламской религиозности в Республике Татарстан. Авторы с помощью историко-сравнительного и причинно-следственного анализа определяют традиционную религиозность данного региона. Под традиционной религиозностью будет пониматься то религиозное течение, которое оказало наибольшее влияние на формирование современной этноконфессиональной ситуации в определенном регионе в рамках конкретного этноса. 
Республика Татарстан в настоящее время является одним из крупнейших регионов РФ по уровню социально-экономического развития. Ислам играет важную роль во всех сфрерах жизни данного региона, поэтому возникает необходимость обозначить, что будет являться традиционным исламом для Татарстана в настоящее время. Для этой задачи необходимо проследить приход и развитие ислама в данном регионе, а также разобрать концепцию "Ислам и татарский мир: концептуальные основы развития 1" принятой при участии ДУМ РТ в 2013 году на IV Всероссийском Форуме татарских религиозных деятелей. Таким образом, можно будет выявить то течение, которое оказало наибольшее влияние на становление современной этноконсеессиональной ситуации в регионе. Сразу отметим, что под традиционной религиозностью в данной статье будет пониматься то религиозное течение, которое оказало наибольшее влияние на формирование современной этноконфессиональной ситуации в определенном регионе в рамках конкретного этноса.

Процесс проникновения ислама в Волго-Камский регион приходился на IX - первую половину X веков, а в X-XI веках он стал государственной религией Волжской Булгарии. Ряд исследователей указывают в качестве основных причин данного процесса наличие социально-экономических связей с государствами Средней Азии, а также генотеистический характер тенгрианства. В данный период отсутствовало господство определенного мазхаба и теологического направления, но постепенно к XIII веку начинает доминировать ханафитский мазхаб².

Монгольское нашествие и ликвидация независимости не привели к существенному изменению религиозной ситуации в регионе, так как конфессиональная политика Чингизидов была довольно терпимой по отношению к другим религиям³. Более того, в 1320-ых годах ислам стал государственной религией Золотой Орды, что еще более упрочило позиции ислама в регионе. После распада Золотой Орды, в 1438 году возникает Казанское ханство, параллельно с формированием новой государственности, в XV веке образовывается татарский этнос. На фоне данных событий, примерно в это же время, в Казанском ханстве официально утверждается ханафитский мазхаб и матуридизм ${ }^{4}$. По причине завоевания Казанского ханства Московским царством в 1552 году, и как следствие, политики насильственной христианизации, был нанесен существенный урон интеллектуальной элите татарского народа, что привело к застою татарской богословской мысли вплоть до середины XVIII века.

Ситуация начала меняться во второй половине XVIII века. В 1756 году было отменено принудительное переселение некрещенных татар и было разрешено строительство мечетей. В 1764 году был отменен дополнительный налог для некрещенных татар, а также была ликвидирована контора новокрещенских дел. В 1773 году был принят указ "О веротерпимости", согласно которому все религии в Российской империи получали право на существование, а также отменялась насильственная христианизация. В 1788 году по указу Екатерины II было образовано Оренбургское магометанское духовное собрание - духовное управление мусульман-суннитов на территории Российской империи. Это был коллегиальный орган, деятельностью которого руководили муфтий и три кади. Формально должность мустия была выборной, но на деле он назначался императором по предоставлению министра внутренних дел. Кади избирались мусульманским духовенством Казанской губернии, а с 1889 года - назначались министром внутренних дел по предоставлению мустти 5 . 
В результате данных реформ татарское исламское богословие вновь получило возможность для дальнейшего развития. Конец XIX - начало XX века стал значимым периодом, ввиду возникновения джадидизма - движения исламского модернизма на территории Российской империи. Изначально данное движение выступало за реформу исламской системы образования, а именно предлагалось ввести в медресе изучение светских наук, а также звукового метода, вместо буквослогательного. Позже джадидизм трансформировался в полноценное религиозно-политическое движение, основной спецификой которого являлись ценность позитивистского прогресса, стремление к вестернизации отдельных сфрер социума, особое внимание к конфессионально-государственным отношениям. Ввиду полемики с кадимизмом и социально-политическим изменениям в государстве целом, отдельные конкретные позиции по тому или иному вопросу менялись. Данная тенденция продолжала сохраняться до начала 1920-ых годов.

Кардинально ситуация изменилась с появлением СССР и его антирелигиозной политикой. Профессиональное исламское образование к концу 1920-ых было фактически уничтожено 6 . В 1948 году было образовано Духовное управление мусульман Европейской России и Сибири (ДУМЕС) и был принят устав, по которому из ведения ДУМЕС были изъяты такие полномочия, как создание медресе и мектебов, организация курсов для подготовки служителей культа, образование мухтасибатов, ведение метрических книг. ЦДУМ сохранило чисто богословские функции, контроль за назначением духовенства, учёт мечетей и молитвенных домов. Такое положение сохранялось до конца 1980-ых годов.

Положение начало улучшаться в период перестройки (1985-1991), в частности, с принятием курса "гласности" в 1987 году. В 1989 году было открыто медресе имени Ризаитдина Фахретдина (ныне Российский исламский университет). Полностью ситуация изменилась с распадом СССР декабре 1991, в связи с чем давление на религии со стороны государства полностью прекратилось. Поворотным моментом также является образование в 1992 году Духовного управления мусульман Республики Татарстан, а также объединение ДУМ РТ и Регионального ДУМ Татарстана в 1998 году, что поспособствовало более координированному и эфффективному процессу возрождения татаро-исламской богословской мысли. Данный процесс продолжается по настоящее время, и он не всегда нес в себе однозначный характер. В 1990-ые годы резко вырос уровень национального самосознания, в связи с чем ислам вновь стал значимым компонентом для этно-конфессиональной идентичности татар. Ввиду этого конфессиональная составляющая активно попадала под влияние национальной и использовалась для достижения определенных политических целей. С другой стороны, происходил процесс проникновения в регион различных исламских течений из-за рубежа, и они, по большому счету, усваивались молодым поколением мусульман 7 . Проблема определения традиционного ислама для Татарстана оставалась открытой до начала 2010-ых годов.

В 2013 году на IV Всероссийском Форуме татарских религиозных деятелей принимается документ, который излагает "базовые положения Ислама и его учения по вопросам государственно-конфессиональных отношений и по ряду современных общественно значимых проблем. Документ также раскрывает позицию татарского мусульманского духовенства в сфере взаимоотношений с государством и светским обществом. Его основным предметом является фундаментальные богословские и социальные вопросы, а также те стороны жизни государства и общества, которые были и остаются актуальными для 
татаро-мусульманского сообщества в начале XXI века и в ближайшем будущем. Концепция призвана стать шагом к консолидации татарского народа на основе Исламских ценностей".

Данный документ имеет следующие двенадцать разделов:

- Ислам в истории татарского народа.

- Богословские ориентиры татарского народа.

- Ислам и нации.

- Ислам и вопросы власти.

- Отношение к проблеме войны и мира. Веротерпимость.

- Экономика и мусульманское общество.

- Мусульманская община (махалля) у татар.

- Мусульманское образование.

- Ислам и семейные ценности.

- Ислам в мультикультурном мире.

- Ислам в инфрормационном пространстве.

- Социальное служение в исламе.

Наибольший интерес представляет второй раздел "Богословские ориентиры татарского народа", в котором указывается, что традиционным исламом будет является суннизм ханафитского мазхаба матуридитского толка. Но также в разделах "Ислам и вопросы власти" и "Мусульманское образование" прослеживается джадидизм. В первом случае, в религиозном ключе аргументируется позиция, суть которой заключается в том, что в исламском мировоззрении духовная и светская стороны общественной жизни изначально разделены. В разделе посвященному мусульманскому образованию утверждается, что исламская система образования должна соответствовать духу времени и быть мобильной в целом.

Таким образом, опираясь на историю ислама в Татарстане, можно сделать вывод, что традиционным исламом для этого региона будет являться суннизм ханафитского мазхаба матуридитского и джадидитского направления. Матуридизм проявляется в теолого-философской сфере, а джадидизм в социально-политической. Также данное положение подтверждает документ, выражающий официальную позицию ДУМ РТ по этому вопросу.

${ }^{1}$ Ислам и татарский мир: концептуальные основы развития - Казань, 2013. - 38 с.

2 Измайлов И.Л. Ислам в Волжской Булгарии: распространение и региональные особенности / История и современность. - 2011. - №2. С. 48.

${ }^{3}$ Адыгамов Р.К. Становление и развитие богословской мысли татар: история и тенденции / Вестник Российского университета дружбы народов. Серия: история России. - 2018. - Т. XVII. - №3. C. 557.

${ }^{4}$ Аксанов А.В. Ислам в казанском ханстве: проблемы и перспективы исследования / Тюркологические исследования. - 2018. - Т. І. - №3. С 64.

${ }^{5}$ Арапов Д.Ю. Ислам в Российской империи (Законодательные акты, описания, статистика). М.: ИКЦ Академкнига, 2001. С. 103.

6 Фахрутдинов P.P. Татарское общественно-политическое движение в конце XIX - начале XX веков: историография проблемы / Вестник Чувашского университета. - 2006. - №1. С 85. 
${ }^{7}$ Мухаметшин Р.М. Ислам в постсоветском Татарстане: обновления и утраты / Россия и мусульманский мир. - 2007. - №12. С. 25.

\title{
ETERMINATION OF TRADITIONAL ISLAMIC RELIGIOUSITY IN THE REPUBLIC OF TATARSTAN
}

\author{
C 2020 Yarullin Ruslan Faridovich \\ Student \\ (C) 2020 Semakina Anastasia Alexandrovna \\ Student \\ Kazan Federal University \\ E-mail: kit.kit@list.ru
} Islam.

Keywords: Islam, Republic of Tatarstan, Hanafi madhhab, traditional religion, Jadidism, history of

The article is devoted to the identification of traditional Islamic religiosity in the Republic of Tatarstan. The authors, using historical, comparative and causal analysis, determine the traditional religiosity of the region. Traditional religiosity will be understood as the religious movement that has had the greatest influence on the formation of the modern ethno-confessional situation in a particular region within the framework of a particular ethnic group. 